\title{
Main Features of the Timber Structure Building Industry Business Models
}

\author{
Annie Gosselin ${ }^{1}$, , Yan Cimon ${ }^{2}$, Nadia Lehoux ${ }^{3}$ and Pierre Blanchet ${ }^{1}$ (D) \\ 1 NSERC Industrial Chair on Ecoresponsible Wood Construction-CIRCERB, Laval University, 2425, \\ Rue de la Terrasse, Quebec, QC G1V 0A6, Canada; pierre.blanchet@sbf.ulaval.ca \\ 2 Interuniversity Research Center on Enterprise Networks, Logistics and Transportation-CIRRELT, \\ Department of Management, Administration Sciences Faculty, Laval University, 2325, Rue de la Terrasse, \\ Quebec, QC G1V 0A6, Canada; Yan.Cimon@fsa.ulaval.ca \\ 3 Department of Mechanical Engineering, Engineering and Sciences Faculty, Laval University, \\ Av. de la Médecine, Bureau 1504, Quebec, QC G1V 0A6, Canada; Nadia.Lehoux@gmc.ulaval.ca \\ * Correspondence: gosselinannie@hotmail.com
}

check for updates

Citation: Gosselin, A.; Cimon, Y.; Lehoux, N.; Blanchet, P. Main Features of the Timber Structure Building Industry Business Models. Buildings 2021, 11, 170. https:// doi.org/10.3390/buildings11040170

Academic Editors: Johannes I. M. Halman and Jimme A. Keizer

Received: 28 February 2021

Accepted: 14 April 2021

Published: 16 April 2021

Publisher's Note: MDPI stays neutral with regard to jurisdictional claims in published maps and institutional affiliations.

Copyright: (c) 2021 by the authors. Licensee MDPI, Basel, Switzerland. This article is an open access article distributed under the terms and conditions of the Creative Commons Attribution (CC BY) license (https:// creativecommons.org/licenses/by/ $4.0 /)$.

\begin{abstract}
The use of timber as structural building material is growing and a greater number of firms are looking to enter this raising market. Erecting a complex timber building usually involves combining the work of architects, structural engineers, builders, suppliers and/or supplier-builders, all of them having their own business models. The purpose of this research was to uncover the specific nature of business models in the timber structure building industry. First, a thorough mapping of these business models was undertaken. Second, underlying patterns were uncovered within these models. A triangulation method of secondary data, semi-structured interviews and participant observation was used to allow for an in-depth study of 23 stakeholder business models. The analysis shows that knowledge sharing appears as crucial and may be achieved through sustained collaboration. As a result, collaborative contract procurement modes seem to be the most appropriate for timber construction. Tight relationships with suppliers and supplier-builders also appear as prerequisites. Furthermore, stakeholder partnerships with universities appear common in the field, while prefabrication is increasing in popularity. These findings can be useful to grasp the prevailing business models in this industry given the sustained growth of the timber structure building market.
\end{abstract}

Keywords: timber building; business models; collaboration; building design

\section{Introduction}

Since the industrial revolution, concrete and steel have been the main structural building materials used for the construction of tall and large buildings. Although timber structures are popular within the residential building sector in some countries, their use is still quite sparse in commercial, institutional, residential multi-story and industrial buildings [1]. However, since the 1990s, an increasing number of these buildings have been built using a timber structure in many countries around the world. The market share for timber structure buildings has grown in recent years [2-6]. For instance, in the province of Québec (Canada), the use of timber for non-residential buildings less than four stories has increased from 15\% to 34\% between 2006 and 2020 [7].

Engineered timber products such as glulam and mass timber panels developed in the last 30 years have opened multiple new building possibilities. To take advantage of these new options, stakeholders in the construction value chain, namely real estate developers, architects, engineers, general contractors, timber builders and material suppliers, will have to adapt their practices, as well as the construction wood product industry [8]. Reinventing the way value is delivered may also involve rethinking some aspects or the whole business model. However, research on the timber structure building industry business models remains at an initial stage at best and few studies have been published on this particular topic. 
The purpose of this research was therefore to uncover the specific nature of business models found in this emerging niche. More precisely, the objective of the study was to identify context-specific contents and potential underlying characteristics within timber structure buildings industry business models. The Osterwalder and Pigneur [9] business model canvas was used to structure data gathering given its importance in the literature. This canvas integrates nine key elements composing a business model: value proposition, customer segments, clients, channels, revenues, key partnerships, key resources, key activities and costs. Secondary data, interviews and participant observation techniques were triangulated to gather relevant information and draw key inferences about those nine key business model elements. Data were then further analyzed to answer the two aforementioned research questions.

In this paper, the theoretical issues that underpin business models are presented, as are the state of research on the timber structure building industry and research efforts on business models in this industry. Then, the triangulation research methodology used to implement this research is discussed as it rests on three strategies: (1) secondary data collection; (2) semi-structured interviews; and (3) participant observation tools [10].

\subsection{Defining a Business Model}

The origins of theoretical conceptualizations around business models coincide with the rise of the Internet in the 1990s. Still at an early stage of its development, the field is undergoing rapid transformation and opportunities for greater formalization abound. Several authors have suggested definitions for the notion of business model [9,11-22]. Business models mostly explain how their different constitutive parts create a coherent model as a whole [11,16]. Timmers [13] put forth the following definition: "An architecture for the product, service and information flows, including a description of the various business actors and their roles; and a description of the potential benefits for the various business actors; and a description of the sources of revenues" (p. 2). Amit and Zott [14] suggested a more concise and value-driven definition: "A business model depicts the content, structure, and governance of transactions designed to create value through the exploitation of business opportunities" (p. 511). Taking a more concrete stand, Magretta [16] made the following proposition that posited the business model as a narrative:

"Business models, though, are anything but arcane. They are, at heart, stories-stories that explain how enterprises work. A good business model answers Peter Drucker's ageold questions: Who is the customer? And what does the customer value? It also answers the fundamental questions every manager must ask: How do we make money in this business? What is the underlying economic logic that explains how we can deliver value to customers at an appropriate cost?" (p. 4).

Morris, Schindehutte and Allen [17], for their part, linked together key ideas from contemporary strategic management: "A business model is a concise representation of how an interrelated set of decision variables in the areas of venture strategy, architecture, and economics are addressed to create sustainable competitive advantage in defined markets" (p. 727). They further identified six fundamental components in a business model: value proposition, customer, internal processes/competencies, external positioning, economic model and personal/investor factors. Gulati [22] went further with an approach that explains how a business should be organized to operationalize the strategy of focusing on-and thus meeting - consumer demand; in other words, a business model explains how to sell solutions that meet the needs of consumers rather than just selling products. Gulati promoted the establishment of four types of actions and attitudes within companies: coordination, cooperation, capacity building and connection. For their part, Casadesus-Masanell and Ricart [21] argued that a business model "consists of a set of managerial choices and the consequences of those choices" (p. 103). Osterwalder and Pigneur [9] devised one of the leading conceptualizations in the field with the following definition: "A business model describes the rationale of how an organization creates, delivers, and captures value" (p. 14). They further decomposed a business model into nine elements: value proposi- 
tion, customer segments, client, channels, revenues, key partnerships, key resources, key activities and cost structure. They devised the following canvas as a representation of business models.

This business model definition and conceptualization from Osterwalder and Pigneur [9] was used to conduct this research because of its importance in the literature (Figure 1). It also was most useful to facilitate the establishment of the semi-structured interview structure and data analyses due to its proximity to the vocabulary used by industry practitioners. Following this model, the value proposition is understood as the services or products the company delivers to its customers to solve their problems or satisfy their needs. Customer segments are customer groups with similar needs, attitudes and habits. Customer relationships define relationships established with each customer segment. Channels are the ways a company interacts with its customers. Revenue streams define the money the company makes from each customer segment. Key activities are the actions a company must undertake to be able to deliver value. Key resources are the resources, financial, material or human, a company uses to deliver value. Key partnerships are the alliances a company forges, usually with other companies, to reduce risk and improve its business model. The cost structure is what it costs to make the business model work.

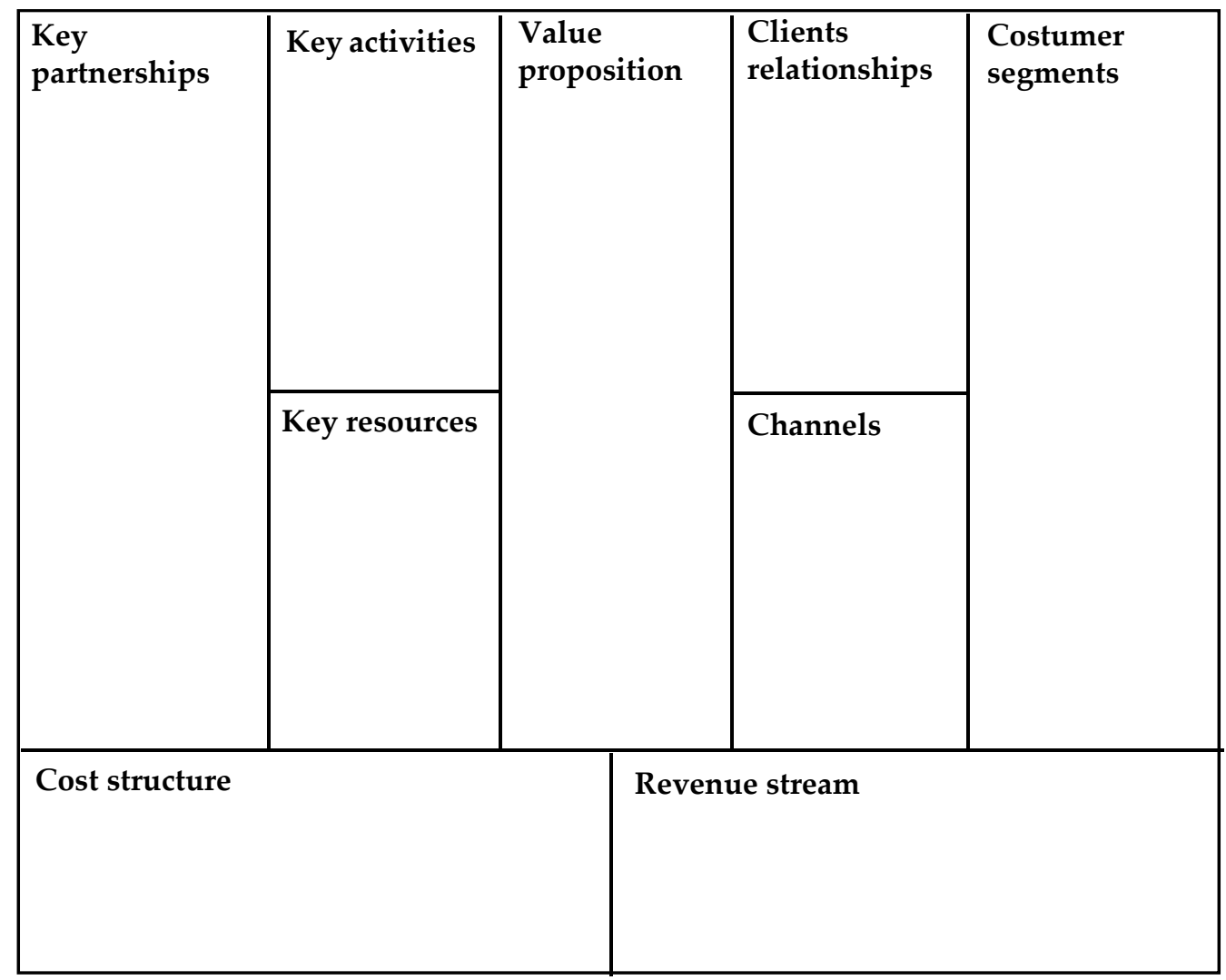

Figure 1. Business model canvas. Image adapted from: Osterwalder and Pigneur [9] (p. 237). Source: Strategyzer.com.

Some studies have been conducted based on this canvas. For instance, Joyce et al. [23] designed the "triple layered business model canvas" to better encompass sustainable aspects into business models and exemplified its use with a Nespresso case. Franceschelli et al. [24] worked on business model innovation for sustainability using this canvas and based on a food start-up case study. Dijkmana et al. [25] developed a business model for the Internet of Things. 
Business Model Innovation

Porter [26] mentioned that, to be competitive, a company must stand out and maintain its competitive advantages over time. As to the competitive specification of today's world, companies should continuously improve their products and services with innovative ideas and be synchronized with their competitors [18,27] for fear of lagging behind within their industry. Bringing innovation to products and services a company's offers has for long time been seen as the way to innovate in business. Another way is to design innovative business models [14]. Companies should thus dynamically renew their business model and think about their long-term growth strategy [12,19,28-32]. Although large-sized companies are more likely to develop innovative business model approaches, Small- and Medium-Size Enterprises (SMEs) should not neglect using this strategy [33].

\subsection{Business Models in the Construction Industry}

Studies related to business models within the construction field argue that the concept of business model is important to consider. However, business models are not much used or are understood differently in the business world compared to academia [34]. The business models described by managers entail project deliverables and contract structures or business segments, rather than how their organizations deliver value to customers. Aki et al. [35] went further and investigated project selection at different firms. Their results show that project selection was not guided by any specific business model, but rather through a decision-making process dominated by short-term factors such as a need for work and profitability. Thus, the estimated expertise largely determines the kind of projects companies are willing to consider, regardless of their ability to deliver them [36].

The pressure to change is another staple of the construction industry. This economic sector also must evolve. For instance, strong attention is given to off-site construction potential and its impact on companies' business models [37-39]. Many studies on business models and offsite construction, prefabrication or industrialization of the construction have been conducted [40-45]. One-stop-shop (OSS) rather than fragmented solution shops is an example of innovative business model in the renovation sector [46].

Going sustainable is another progress the construction industry will have to undergo [47]. This trend is supported by different building certification schemes such as LEED, BREEAM, DGNB, PassivHaus, HQE, etc. Unfortunately, knowledge about appropriate business model to put in place to support green transitions in not recognized enough [36,48-50]. For instance, according to Aha [51], prices and earnings must genuinely relate to performance delivered to customers and society and incentives should be given to long term service levels and performance of actual facilities while empowering professionals within the enterprise acting accordingly to long term objectives. Business models for zero carbon building adaptation have also been explored [52-55] as well as business models to enhance circular economy [56-58].

\subsection{Business Models in the Timber Structure Building Industry}

Research on business models in the timber structure building industry is rather scarce. Brege et al. [59] studied the link between business models and multi-unit buildings. Their multiple case studies include five major Swedish companies producing prefabricated timber building components. Their conclusions suggest that prefabrication should be the main element of business models and the rest of the model should be adapted to this core. Mayo [60], who studied the cases of thirty non-residential timber buildings, also suggested prefabrication will be central to wood construction practices in future. Höök et al. [61] investigated the impact of managing strategy with a portfolio of business models in a Swedish supplier of building components and systems and found their use can help gain achievements and facilitate management change in a company. A report produced by Michaelsen and Tran [8] highlights the trend of selling building system components that will affect the organization of value chains and the interactions within members 
of this chain. Furthermore, structural timber building business models need to include partnerships and alliances within the value chain [62].

\section{Materials and Methods}

To map timber structure building industry business models and identify common as well as distinctive elements, this work was based on the following hypothesis: since timber structure building industry is more fragmented, young and less mature, its business model will be different from steel and concrete structure building industries. Two research questions were also used: (1) Are there patterns into business models studied? (2) Which features the business model of timber structure building industry integrate? To answer those two questions, data were collected using a multi-method data collection procedure with a view to triangulating the results offered by these techniques. According to Mathison [10], triangulation ensures "various data sources and methods to lead to a singular proposition about the phenomenon being studied". For this research, the studied phenomena is the timber structure building industry business models.

First, secondary data were gathered from business documents produced by professional bodies linked to the industry. They are easy to find but not complete. Second, 23 semi-structured interviews were conducted to deepen the insights and findings gathered while mining the secondary data. Finally, participant observation was used to better contextualize how business models and their constitutive dimensions could be refined while allowing for a deeper understanding of the context for their application through on-site field observations. These three qualitative research tools used together ensured the validity and reliability of the results [63,64].

\subsection{Methodological Tool 1: Use of Secondary Data}

Secondary data are mainly data coming from studies made by others [65,66]. Prior to completing the field portion of the research, an initial survey of the technical, trade and scientific literature was carried out on fifteen European timber structure buildings. These were selected because they are globally recognized flagships timber building cases and because multiple documents, articles, technical reports and grey literature documents related to them were readily available. There are among the first timber buildings recently build pushing heights and size common limits requesting the use of timber engineered products and most have been discussed and studied a lot. The names of those buildings could not be disclosed for confidentiality reasons since the executives met felt that outright disclosure would damage their firms' respective competitive advantages. For every main stakeholder member of the value chain who participated in the completion of these fifteen buildings (realtors, architects, engineers, builders and suppliers), respective corporate websites and documentation were also analyzed in depth using the business model framework suggested by Osterwalder and Pigneur [9]. Those five stakeholders were chosen because they are the main actors of construction projects as explained above and the ones spending a lot of time on every project they participate to. Then, through the analyze, sixty company business models were then detailed prior to field interviews. As mentioned above, fifteen recently built flagship timber buildings were selected, and, for each of them, the value chain's five main stakeholder companies' business models were mapped. This served to mitigate the empirical risks to the validity and reliability of this research associated with the confidentiality agreed upon for the fifteen globally recognized European projects examined in earlier stages.

Secondary data were also used during and after the three-month field interview period carried out to gain a finer-grained understanding of the issues faced by stakeholders and to enrich the information gathered using other methodological tools described hereafter. Before every interview, the respondent's company websites were consulted to add extra contextualization to the questions. Some technical booklets, company reports and marketing documents were gathered after the interviews, most of which came directly from respondents themselves, other materials were sometimes provided by their personnel. 
These were later used in the process to enrich the data output from the interview or to better contextualize it.

\subsection{Methodological Tool 2: Semi-Structured Interviews}

The fifteen European timber structural buildings originally selected for this research and mentioned above include diverse building types: multi-story residential buildings, cultural centers, hotels, institutional and office buildings. The architectural and engineering firms, the construction company and the timber material supplier for each building were identified and contacted through various channels (e.g., e-mails, LinkedIn, etc.). As explained above, they are the professionals having spent more time working on these building and the ones having more to say about. Sixty contacts were initiated and twelve provided positive responses, meaning 48 respondents did not answer, were not available or were not willing to participate to the study. The initial round of interviews was carried out in person at the location of the respondent, thereby allowing facility/project visits at the same time. Interviews were conducted in nine countries (Austria, Germany, Switzerland, Italy, England, Scotland, Norway, Sweden and Denmark) over a period of three months. Many of the respondents suggested we interview other leading timber structure building companies located in the same areas. Thus, a second round of interviews was carried out leveraging these opportunities through a snowball technique that helped gather more respondents [67]. The sampling was deemed complete when further interviews did not uncover new elements thus indicating that the sample saturation effect was then reached, a process consistent with recommendations in the literature $[68,69]$.

Finally, the two rounds of interviews generated a total of 23 interviews lasting between $30 \mathrm{~min}$ and $2 \mathrm{~h}$ each. This allowed for business model mapping to be conducted for nine architectural, five structural engineering and three building firms, as well as for three engineered timber products suppliers and three supplier-builders. In addition to the 23 interviews mentioned above, six additional interviews were arranged and are detailed as follows: one with a wood board supplier, two with wood building technology developers and three with leading academics of international stature recognized in the field. These interviews were useful in two ways. First, they helped reach a broader understanding of the industry as a whole beyond the specialist perspectives derived from previous interviews. Second, they were used for their confirmatory value and to increase the validity of our research, which is why their own business models were not mapped. As such, 29 interviews were conducted (see Table 1).

Table 1. Interviews sample details.

\begin{tabular}{ccc}
\hline Expert Categories & $\begin{array}{c}\text { Number of } \\
\text { Interviews }\end{array}$ & Countries \\
\hline Architects & 9 & $\begin{array}{c}\text { Austria, Denmark, England, } \\
\text { Germany, Italy, Sweden, Switzerland }\end{array}$ \\
\hline Structural engineers & 5 & $\begin{array}{c}\text { Austria, England, Norway, } \\
\text { Switzerland }\end{array}$ \\
\hline Builders & 3 & Austria, England, Norway \\
\hline Suppliers-Builders & 3 & Austria, Germany \\
\hline Engineered timber product suppliers & 3 & Austria, Norway, Scotland \\
\hline Wood board supplier & $1^{*}$ & Sweden \\
\hline Timber building technology developers & $2^{*}$ & Scotland \\
\hline Academics & $3^{*}$ & Austria, Germany, Scotland \\
\hline Total & 29 & 9 countries \\
\hline
\end{tabular}

Note: * indicates confirmatory interviews.

The interviews were conducted with one or two members of each company contacted. All research participants gave their appropriate informed consent by signing a consent 
form. Interviews consisted of 30 open-ended questions included in an interview guide [70] (see the Appendix A). These questions were based on the various dimensions laid out by Osterwalder and Pigneur's [9] business model conceptualization. Semi-structured interviews and open-ended questions were preferred since they allowed respondents to express complete ideas, experiences, opinions and feelings from their own perspective [71]. Two main themes were addressed: (1) the respondent's experience related to the construction of timber structure building; and (2) their company's business model. Themes were broken down into variables. The first variables were linked to the respondent's experience with timber structure building projects (reasons for using wood, number of timber buildings realized, positive aspects related to their experiences, challenges, intention to go on with more of them, etc.). The variables of the second theme were the nine business model elements suggested by Osterwalder and Pigneur [9] in their above-mentioned framework. The interviews lasted between 1 and $2 \mathrm{~h}$. Although the questions were determined beforehand, they were asked in a way to keep the conversation fluid. New questions were adjusted while remaining faithful to the original research objectives [72]. The interviewer made sure the discussion focused on the theme and variables previously mentioned. In the Result Section, to ensure confidentiality, respondents are identified by codes. The data gathered henceforth were further improved upon with participant observation.

\subsection{Methodological Tool 3: Participant Observation}

The third methodological tool used was participant observation. Participant observation is a methodological tool derived from the qualitative research methodology where the goal is to see and experiment a social phenomenon and its mechanisms from the inside $[70,73]$. The researcher's goal is to then get as close as possible to reality as lived by the actors [74]. Mintzberg [75] used the terms direct research to express this simple way of visiting professional offices. Three months were spent in the field (Europe). Most respondent offices and/or building projects were visited during interviews. Documents, resources and company workers were observed. Three plant tours were also carried out. Free-flow field notes were taken. All the information gathered was then analyzed using a qualitative approach and the content analysis method.

\subsection{Qualitative Analysis}

A qualitative approach was used to analyze the data. This method consists of describing the specific characteristics of different elements (words, phrases, ideas, etc.) grouped together into categories, which emerge in addition to their quantitative meanings. The essence of the phenomenon studied resides in the nature and in the very specific content of the data analyzed, rather than only in its quantitative characteristics [76]. The three tools generated a lot of material that had to be filtered and categorized. The use of unpublished data must be carefully set [77] as not to delve into meaninglessness. Qualitative analysis is the main thread of content analysis in its search for meaning. It consists of a careful description of the various particularities which emerge from the compilations $[66,70,71,78,79]$.

Content analysis of secondary data, answers to interviews and field notes was rigorously conducted to ensure reliability and validity of results [80]. A systematic procedure was followed to ensure the credibility of the research [81]. According to the research variables described above, a code system was established and coding performed [82]. The nine elements included in the business model proposed by Osterwalder and Pigneur [9] could thus be described and key factors they should include if an enterprise is to get involved into timber structure building projects identified.

\subsection{Literature Review}

To ensure relevant literature written about business models in the construction sector in general was found, systematic queries were performed. As a second step and to also find existing material on timber structure enterprises' business models, a critical review process was conducted. 
The systematic queries began with the selection of relevant databases based on their specializations. Five were identified, three from the engineering field and two from the management field: Web of Sciences, Compendex, Inspec, ABI Inform and Business Source Premier. Their selection allowed covering construction and business modeling topics. After many trials using a broad variety of related terms (construction, building, business models, collaboration, collaborative business mode, shared business model, value co-creation, innovation network, innovation ecosystem, value generating and co-creation), the following keywords were selected and combined to conduct queries in the five databases mentioned.

1. "construction"

2. AND "building"

3. AND "business models"

The related results were considered the most accurate and it was possible to deal with their number. Query 1 was conducted on Web of Sciences, Query 2 on Compendex and Inspec jointly, Query 3 on ABI Infom and Query 4 on Business Source Premier. No year limits were imposed and conference proceedings and academic articles were accepted since a high degree of precision and reliability was needed. Duplicates were eliminated and 176 articles remained. After screening the titles and abstracts, 55 articles were judged eligible. Records were mainly rejected if about water management, high technologies, building information modeling, the Internet of Things or life cycle assessments. From the eligible articles, 29 were included in either the Introduction or Discussion Section of this article. Figure 2 schematizes the results obtained.
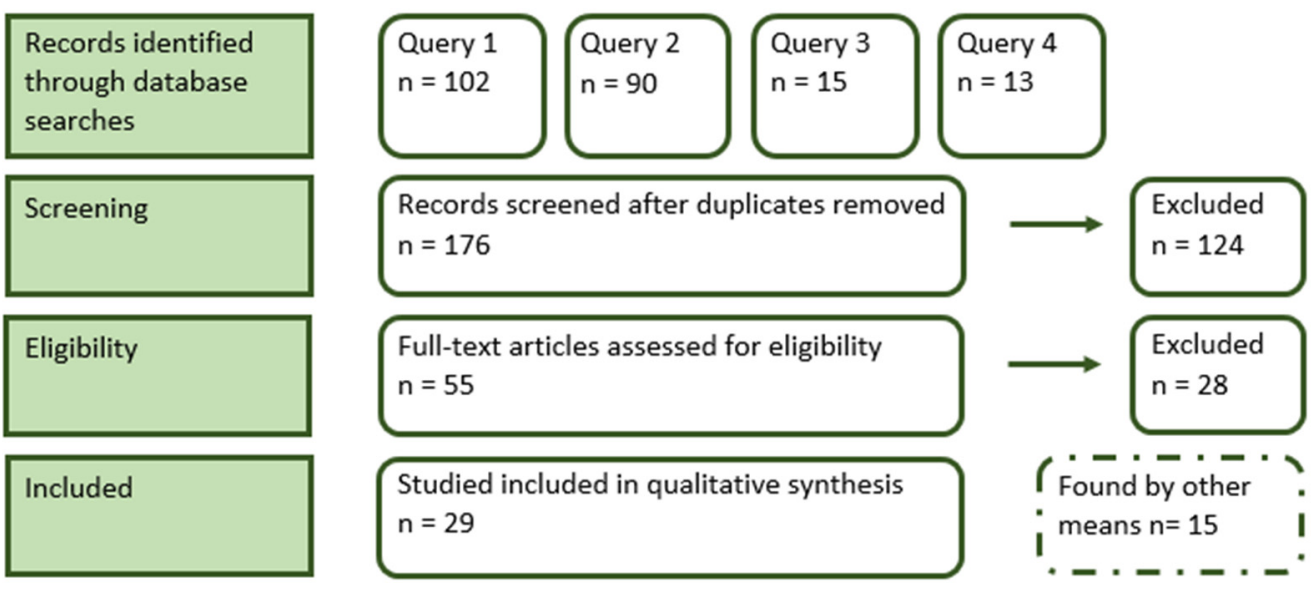

Figure 2. Results of the systematic queries; adapted from the PRISMA flow diagram [83].

Fifteen articles found by other means were discovered using critical review process. A critical review process implies the combination of strategic searches: building blocks, citation pearl growing, successive fractions and berry picking (see Table 2).

Table 2. Search strategies used for the critical review of the relevant literature; adapted from Booth [84].

\begin{tabular}{cl}
\hline Building Blocks & $\begin{array}{l}\text { Subdividing a search query in multiple variants and combining them } \\
\text { using Boolean operators }\end{array}$ \\
\hline $\begin{array}{c}\text { Citation Pearl } \\
\text { Growing }\end{array}$ & $\begin{array}{l}\text { Scanning relevant article to find additional relevant terms to add to the } \\
\text { search strategy }\end{array}$ \\
\hline Successive Fractions & $\begin{array}{l}\text { Searching databases using relevant terms found in relevant articles } \\
\text { with the AND operator }\end{array}$ \\
\hline Berry Picking & Scanning articles for relevant references, citations, authors and journals \\
\hline
\end{tabular}


Building blocks and successive fractions strategies were performed using Boolean operators AND and OR in different databases: Web of Sciences, Compendex, Inspec, ABI Inform, Business Source Premier, Université Laval's Library database Sofia and Google Scholar. Keywords mentioned in Table 3 were added progressively while conducting the searches.

Table 3. Keywords used to complete the critical review.

\begin{tabular}{cccc}
\hline Primary Keywords & Secondary Keywords & Tertiary Keywords & Quaternary Keywords \\
\hline Construction & Building & Business models & Value proposition \\
\hline & Timber building & Collaboration & Clients \\
\hline Wood building & Collaborative business model & Costumers & Channels \\
\hline & Shared business model & Revenue \\
\hline & Value co-creation & Resources & Activities \\
\hline & Innovation network & Cost & Innovation ecosystem \\
\hline
\end{tabular}

Citation pearl growing and berry picking strategies were useful to find and select more related articles, authors and journals. Searches were stopped when no more new material could be found. Saturation was reached [85].

\section{Results}

Here is the description of the results found presented according to the nine elements of Osterwalder and Pigneur's [9] canvas.

\subsection{Value Proposition}

\subsubsection{Architects}

Architectural firms offer services. Real estate developers need architects to design buildings they want to build. Architects' value proposition involves creating built or living environments to the clients' satisfaction. To do so, they design at different levels of detail. Most of the architects met demonstrated a strong preference for pursuing detailing to its final stage: "If we design it, we're going to detail it, and build it, and do those things we don't like to stop doing after planning, and we don't like to take other people's work and turn it into details for construction (A010)". Depending on the contract procurement mode used, they also offer project management. An interesting aspect encountered in the field was the willingness of some architectural firms to help their competitors. As an example, one of the architectural firms met offers training sessions to other architectural firms. Knowledge sharing and collaboration thus seems to be part of the value proposition of some architectural firms. However, integrating sustainable development and/or energy efficiency into the design appears as most important for them.

In addition, architectural firms having the competency to design buildings while having in mind how timber structures will be used greatly help engineers to design timber structures in less time, less energy and at better cost.

\subsubsection{Engineers}

The value proposition of engineering firms is to offer structural design. Engineers work to produce detailed designs based on architectural designs, which can also include connector designs. "So the client had the architect's design and then on that one, we worked for the client with the architect up until sort of a detailed design. [...] and did the connection design as well (A013)". Depending on the contract type, structural 
designs can be required at three different levels of detail, namely building design, detailed building design and piece design, which includes connectors, "how many screws, how many holes, where should the holes for the screws be (A017)". The third design level is usually done by suppliers, but engineering firms can be sub-contracted. Structural design encompasses different calculation types, statistical calculations as well as fire and wind protection. All these structural design calculations need to be performed according to relevant building codes in countries where the building is built. "In this project I was involved in global aesthetics and the dynamic calculation for the project (A017)". Engineers' value proposition also integrates the willingness and ability to collaborate with suppliers and supplier-builders to make sure that the decisions they make are compatible with the rest of the value chain needs.

\subsubsection{Builders}

Builders' value proposition is the installation of timber structures. They can also act as general contractors following client preferences and provide support in structural design if needed.

\subsubsection{Suppliers}

The value proposition of suppliers is the production of various engineered timber products including Glued Laminated Timber (Glulam), Crossed Laminated Timber (CLT) and/or Laminated Veneer Lumber (LVL). They produce the timber elements based on calculations achieved by the structural engineers. Thus, suppliers' value proposition offers early involvements in the process so they can influence the drawings, thereby insuring the elements will be produced by their respective mills. Just-in-time deliveries also appeared as part of suppliers' value proposition.

\subsubsection{Supplier-Builders}

Supplier-builders are typically responsible for building wood structures and delivering and installing them on site. They often prefabricate timber elements or modules. "What we deliver [...] is the skeleton, the timber skeleton of the building. Meaning, a lot of timber columns, a lot of timber beams, diagonals, CLTs, staircases, elevator shafts. [...] We deliver that as a self-standing structure (A016)". Supplier-builders' value proposition also involves taking part in the design in the early phases of the projects to make sure calculations and proposed structures can easily be produced and installed.

\subsection{Customer Segments}

\subsubsection{Architects}

Clients of architects are governments, real estate developers and contractors. Architects prescribing wooden structures can either work only with wood or also with concrete and steel. Some architects focus exclusively on a specific building type, they accept both private and public contracts and work with different contract procurement modes. Their geographic markets are mostly regional, with some projects led internationally.

\subsubsection{Engineers}

The engineers have the same clients. Connections with architects are also important, since engineers can be referred to clients by architects. The engineers met were mostly timber specialists. Some smaller companies, mostly freelancers, work exclusively on wooden structures. Timber frame, CLT, glulam and prefabricated projects can be executed. Medium-sized companies focus on timber but also work with other material. The biggest companies work with all kinds of material and timber is given to a specialized department. The engineering firms met had contracts from both the public and private sectors and all types of contract procurement modes were used. Some companies favor specific building types such as schools, educational projects, multi-stories and airports, while others work on everything. Their geographic markets are generally regional. 


\subsubsection{Builders}

Clients for builders can be public entities or private project developers, but they can also be architects. For the building license seller met, clients repeating multiple identical projects (projects that do not build only once) are the ones targeted. They can work with all types of materials and some are timber specialists. Builders work on public and private buildings through different contract procurement modes. Some general contractors will take charge of the erection of timber structures, but they can also sub-contract. Markets can be regional or global.

\subsubsection{Suppliers}

Clients for suppliers are the construction companies. One of the suppliers interviewed has segmented its clients into three categories (A, B or C) according to their consumption habits. "Client $A$ " is a client that always buys from them, "Client B" is a client that buys from them but also from others and "Client $C$ " is a client that does not always pay his bill on time. The idea is to encourage " $\mathrm{B}$ " clients to become " $\mathrm{A}$ " clients and for "Cs" to become "Bs". Suppliers are timber specialists; they work on public and private contracts and with all types of contract procurement modes. The three suppliers met are developing very dynamic markets worldwide.

\subsubsection{Supplier-Builders}

Supplier-builder clients are governments, real estate developers and contractors. They are timber specialists. The first supplier-builder met offered different products, but also focused on the very specific private market of high-quality regional hotels offering between 30 and 60 rooms. They refuse larger projects. The second supplier-builder interviewed offered glulam supplies to building and electricity projects and other types of infrastructure. Its market is mostly in the countryside and is private. They work with different contract procurement modes. The third, which offers timber frame prefabricated systems, mainly supplies public projects in its own country. They mainly work in the design-build contract procurement mode where they also act as general contractors, but they can only supply the material. They offer three types of prefabricated element packages: standard, plus pack and enhanced. They can supply their timber kit to other construction companies.

\subsection{Customer Relationships}

For the five stakeholders, all contracts are realized through dedicated personal assistance from experts. Work relationships are based on personal meetings and completing building projects. When working on public contracts, customer relationships are built through competitions since the stakeholders work together and get to know each other. For private projects, stakeholders have stable clients and relationships: these are the ones they work with repeatedly. Long-term relationships do not generally require efforts to maintain these links. New customer relationships are developed through the channels described above.

\subsection{Channels}

\subsubsection{Architects}

The architect's new clients are mainly reached through marketing strategies. Small firms either do not promote themselves or work with a marketing agency. Big architectural firms either work with marketing agencies or have a marketing department in their organization. Some offices expect their professionals to recruit as part of their mandate. Architects also develop relationships with potential clients when they work on high profile buildings, win a bid, have a good reputation, are recommended by others or when their names are spread through word of mouth. Visits of building sites are also offered, some being public, others exclusive. Articles are published in specialized magazines, newspapers or architectural journals. Many companies participate in conferences, make presentations of specific projects, do television interviews and exhibits and prepare client events. Some 
also teach at universities. Webpages and flyers are also used. Finally, employee movement from one firm to another also contributes to the development of customer relationships.

\subsubsection{Engineers}

For engineers, having good relationships with architects is a key factor. Architects can refer engineers for specific projects. Some engineer firms have marketing departments. A good way for a firm to become known is to participate in conferences and presentations. Word of mouth is also a common way to recruit new clients. Personal contact is key when new projects are announced; calls are then made, or emails sent.

\subsubsection{Builders}

For builders, real estate developers and architects are important. One of the companies met does no marketing at all, the other two promote their services. In some cases, connections are unaided since old clients always come back. When required, international or local visits of offices or buildings are organized, and employees participate in exhibits and conferences.

\subsubsection{Suppliers}

Suppliers seek long-term relationships and try to develop new ones. Clients come to them because they are sometimes unhappy with other suppliers or because of their good reputation. Suppliers become known through word of mouth, or because they write guidelines, data sheets, test results and communicate these and participate in events such as fairs. They also do the usual marketing, use the web, ask for feedback and count on press releases. Personal meetings and visits to other stakeholders in the region and to potential international clients can also occur. The goal of the latter might be to learn how to adapt their processes to the laws and regulations of foreign countries. To popularize its new products, one supplier launched its products by sending sample boxes that were sent to thousands of architects. They also created a book for engineers which integrates all the engineering aspects available in four languages. It can be downloaded for free from their website. They also count on their history of good service.

\subsubsection{Supplier-Builders}

One of the supplier-builders met does no marketing at all and has a full calendar. Clients come by themselves. The other two supplier-builders interviewed participate in fairs to exhibit their products and educate people. They give lectures at conferences and sometimes invite people to their factory or for lunches and organize private meetings. They build their networks. Many of their large projects promote their companies naturally since journalists write about them. The biggest supplier-builder company met had a marketing and a communication department and had special funding to make videos and maintain a website and a Facebook account.

\subsection{Revenue Streams}

\subsubsection{Architects}

Projects are usually charged per hour: "We charge per hour. And we try to increase the rate charged every year (A019)". One architect specified that revenues can also come from savings achieved on a specific project: "It could be a model with a client saying, "Okay. I have a 50 million euros budget. If you build this with the contractors that I tell you for 48 million, we get $20 \%$ of the saved money" (A009)". Another architectural firm invests its revenues: "We don't get money now. We invest in our work. And then we get the money when we sell the houses (A019)". It was also mentioned that, since using structures made from engineered wood product is new, it is sometimes more difficult to make profits. 


\subsubsection{Engineers}

For engineers, revenues come from their clients: "it's the clients, it's the subcontractors, it's the developers. Whoever is our client, is the source of our revenues (A013)". An engineering firm's revenues come from the number of hours they spend working on their projects: "it's hours. We sell the hours (A017)". Flat rate, a percentage of the total cost of the building, is another way they are paid. Presenting at conferences can be another source of income: "We get a little bit- if some people go and speak at something, and they get sponsored to go there, but I mean, it's tiny compared to everything else (A013)".

\subsubsection{Builders}

Builders make money with project management and savings they make on the estimated costs of projects. Their revenues come from: "The big or not big cheques (A018)".

\subsubsection{Suppliers and Supplier-Builders}

Main income for suppliers and supplier-builders is the sale of the material they produce.

\subsection{Key Activities}

\subsubsection{Architects}

The main activity of architectural firms is to develop concepts and draw plans. Depending on the procurement mode, project or site management can also be an important activity for architects. Sometimes, architects also determine the building costs, find construction companies, make connections, participate in construction meetings and supervise construction on site. Some of the bigger architectural firms met have a research unit, an urban design department or an interior design section. Some professionals are involved in teaching wood design expertise either at a university or to other architectural firms.

\subsubsection{Engineers}

Engineers produce plans and calculations for projects of different sizes. Depending on the contract, structural designs can be required at three different levels of detail: building design; detailed building design; piece design, which includes connectors, "how many screws, how many holes, where should the holes for the screws be (A017)". The third design level is usually done by suppliers, but engineering firms can be sub-contracted. Structural design includes considerations for services, seismic activity, fire and acoustics according to relevant building codes.

\subsubsection{Builders}

Builders mainly manage projects. They can either do overall site management and hire a sub-contractor to erect the timber structure or do all the work themselves. Given their expertise and depending on the contract type, builders specialized in timber structure can be asked to detail the structural design to make it producible by the supplier if the "design and build" contract procurement mode is used. They then order the material and install it.

\subsubsection{Suppliers}

The suppliers' key activity is to produce and supply the engineered wood products. To do so, they must often adapt the structural design they receive. To develop the business (building systems) and its markets, they write guidelines, although "competitors can have access to the design and repeat it, but this is what we have to do to create the markets (A001)". They also put in place certification standards. They transfer knowledge to architects, engineers and builders and do market research. They also deliver on site. They can offer technical or consulting services, online services, sales and research and development. They are often involved in the early phases of projects; they consider assisting architects and engineers as part of their activities. 


\subsubsection{Supplier-Builders}

Supplier-builder activities are similar to those of suppliers, but they also install the structure on site. When they prefabricate, the production process includes more steps and needs more time.

\subsection{Key Resources}

\subsubsection{Architects}

Architectural firms mostly hire architectural staff, integrating senior and junior professionals with university backgrounds. Many timber design architects have a strong interest in sustainability. Hired architects mostly learn and are trained once hired. One architectural firm also hires engineers to make sure designs are acceptable from an engineering point of view. Depending on the size of the company, managers, project managers, construction site managers, administration, marketing and financial positions are part of the structure. Architects need an office and material resources.

\subsubsection{Engineers}

Wood structure engineers are civil engineers. Their timber skills are mostly acquired after they are hired. They may have followed wood related courses as part of their degree. There is a shortage of structural engineers that are specialized in wood structures. The expansion of structural engineering firms is limited by the lack of competent and experienced engineers. Employee or timber structure specialists within firms are limited; they ranged from 1 to 15 for the firms interviewed. Internal knowledge transfer is then very important. Employee movement from company to company is an issue. To perform their work, engineers need an office and general software, 3D design software and general office materials.

\subsubsection{Builders}

Builders generally hire carpenters, but, in Norway, timber workers have an advanced diploma that allows them to build wooden structures. Civil engineers or workers with technical diplomas are generally those in charge of the projects. Builders also need offices and general software, 3D design software and general office materials.

\subsubsection{Suppliers}

Suppliers hire carpenters to work in their mills. Workers with more experience manage the operations. The management teams include all business departments. There is an emphasis on "Research and Development" and "Marketing" because building wooden structures is relatively new. The mills are in rural areas and they have offices in cities where engineers and other specialists prefer to live. Having an engineered wood product business in the southern region of Germany and/or in Austria seems to be easier and provide a competitive advantage since universities in the area teach wood structure specialties. Suppliers own factories and machines where they produce engineered wood products. They own or hire subcontractors to deliver. The suppliers have sales offices in many countries.

\subsubsection{Supplier-Builders}

Supplier-builders also hire carpenters to work in mills and have a well-organized management team. They face the same issues as suppliers, as well as own factories and machines where they produce engineered wood products.

\subsection{Key Partnerships}

In this section, partnerships are understood as official agreements between two stakeholders. They imply formal contracts. Most of the time, respondents preferred talking about collaboration relationships shared with other stakeholders. Gosselin et al. [86] identified collaboration relationships between stakeholders in structural timber building 
supply chains. In this study, collaboration relationships refer to informal exchanges of various sorts.

\subsubsection{Architects}

When asked about their partnerships, architects mentioned their contracts with other architectural firms to complete a bigger project or subcontracting during a project. Sometimes they will get together with another architectural firm and no contract is involved. One of the firms specified having collaborations with other architectural firms to transfer knowledge. This same company has created a sister company to construct a building. At least half of the nine architectural firms met mentioned collaborative research projects with universities. Some of these architects are, or were, university lecturers.

\subsubsection{Engineers}

Engineers mentioned having stable work habits where collaboration and team work functions well. Some of them are, or were, university lecturers.

\subsubsection{Builders}

Builders also have repetitive collaborations with engineering firms. One of them mentioned having had a closer than usual relationship when working on a specific timber building. They drove to the supplier "to learn about the product and each other and establish a tighter relationship (A018)". Builders also share contractual relationships and collaborations with other stakeholders.

\subsubsection{Suppliers}

Suppliers also develop partnerships with universities. A large proportion of their research and development is done through academic studies.

\subsubsection{Supplier-Builders}

Supplier-builders also work with universities. They usually use contracts to subcontract engineering services, and they can set up consortiums or joint-ventures when projects are too big. "Sometimes our competitors become collaborators (A016)".

\subsection{Cost Structure}

\subsubsection{Architects and Engineers}

In the UK, the largest expenditure for architects and engineers is rent. Elsewhere it is labor or working hours: "It's about 75, 80\% of the budget (A022)", that are the most expensive. Wood expertise training is also costly: "The teaching of all the people (A004)". Deadline extensions also represent costs or money lost. Research also costs money, but itcan sometimes be used as a tax deduction. Buying computers, software and marketing were also mentioned.

\subsubsection{Builders}

For builders, in one case, "builder's salaries are 30\%, materials are $30 \%$, and subcontracting is $40 \%$ (A018)". Overall, labor and product purchases seem to be the costliest.

\subsubsection{Suppliers and Supplier-Builders}

For suppliers and supplier-builders, raw material, employees and electricity were mentioned as the costliest. Fire and acoustics were cited as the most important cost drivers in wood construction. A supplier-builder explained: "Our employees and our material, the wood we buy, and whatever, and the whole material, [ ... ] this is probably half of it and the other half is subcontractors. So you can say $25 \%$ employee cost, $25 \%$ material, $50 \%$ subcontractors (A007)". Investment in the development of the product and certification and adaptation to construction industry regulations is major for suppliers and supplier- 
builders. They are the ones having to prove the product they are offering respects laws and regulations and is the best option.

\section{Discussions}

Putting the pieces together: Mapping business models of the structural timber building industry were combined with the Osterwalder and Pigneur [9] canvas and the analysis conducted. Thus, the structural wood building business models of the industry could be resumed and mapped as follow.

\subsection{Features of the Timber Structure Building Industry}

Figure 3 demonstrates key factors and features of the timber structure building industry. There are some specific features pertaining to the timber structural timber building industry, and some are also shared by the construction industry in general. They are presented through next lines.

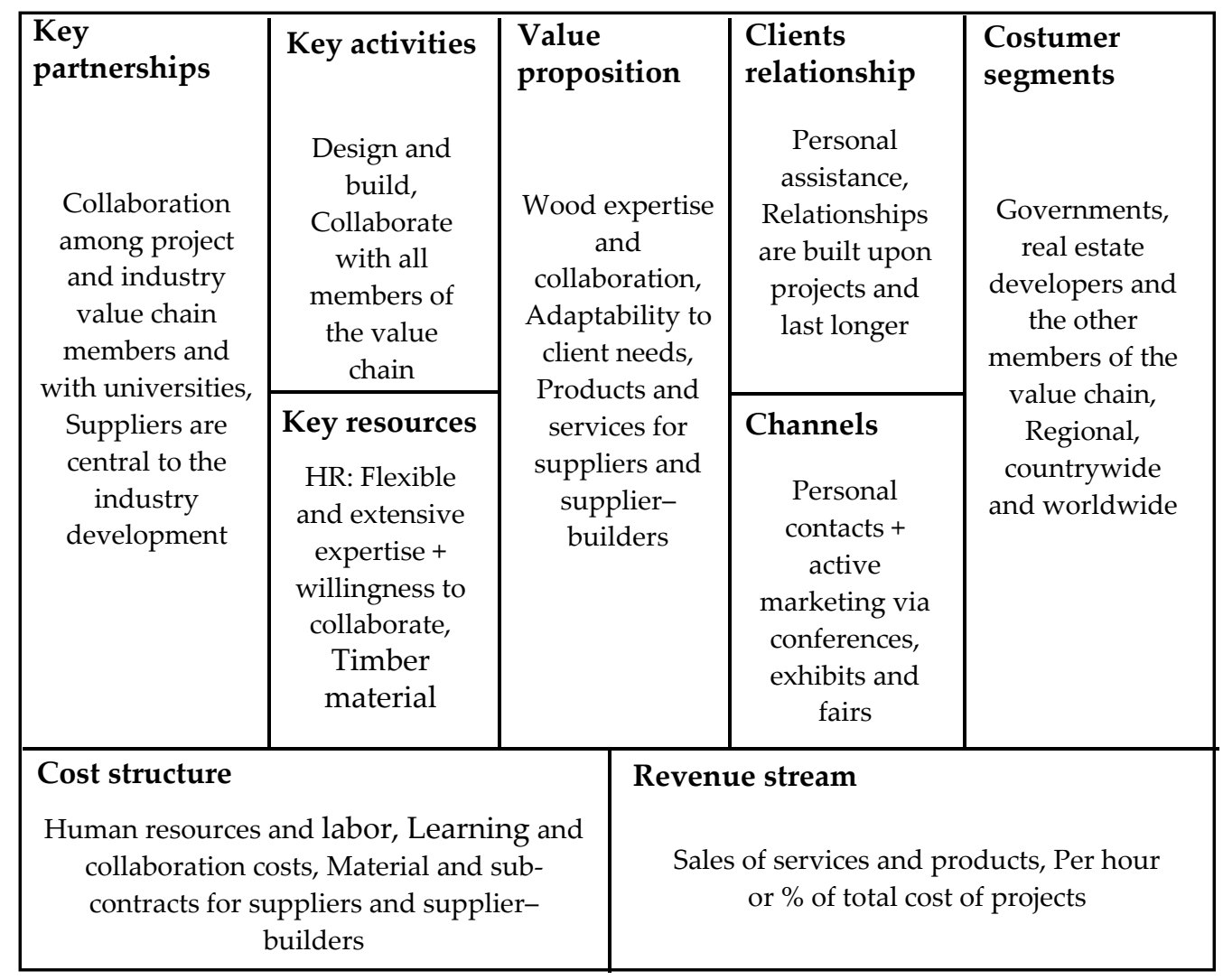

Figure 3. Timber building industry business model summary.

\subsubsection{Similarities and Distinctions among Stakeholder's Business Models}

All stakeholders have different value propositions, but all of them include services. Suppliers and supplier-builders' value proposition also integrates the fabrication of products. Relationships within the value chain are mostly built through projects completion and personal relationships. It should be noted that participation to conferences and shows is very central to the development of all stakeholder's businesses and relationships. A main distinction within the chain relates to customer segments. Suppliers rather aim at worldwide markets for their products, whereas architects, engineers, builders and supplierbuilders rather have local or regional markets. There was an exception for one architect and one engineer interviewed: they are known internationally and work in many countries. This happen when the professional is highly specialized and experienced. Architects' and engineers' revenues are mostly made per hour. Builders, suppliers and supplier-builders 
often are remunerated based on projects deliveries. Key activities of all stakeholders integrate collaboration aspects. Finding the right human resources is often an issue. especially for engineers. Expertise is difficult to find. Partnerships are key to the industry and generally involve unformal collaboration especially with suppliers since they are leading the industry development. Costs most of the time include training of workers.

\subsubsection{Early Stage of Maturity: Mostly Small Businesses for Now}

Most structural timber building enterprises are small businesses. This is especially true for architect and engineering firms. Builders and suppliers-builders can also be reasonably small. Somme suppliers too although some are pretty big. It can be partly explained by the fact that the structural timber building industry is not matured yet. It is still growing fast and it creates a strongly dynamic industry where all players must continuously adapt their practices and business models. The business models mapped here is thus called to change over time, it is a growing industry business model.

\subsubsection{Sustainability Is a Strong Motivation, Especially for Architects}

When asked why enterprises choose timber, sustainability efforts and interests in greening buildings are the main reasons mentioned. This is especially true for architects since all interviewed firms answers incorporated allusions to "being good for the environment". Stakeholder engagement is common to green businesses [87]. This is an argument often used to sell and propose wood as structural building material. It has been proved that timber elements production emits less GHG emissions and stores more of them during building lifetime [88].

\subsubsection{The Suppliers Are the Industry Development Leaders}

The data gathered in this study indicate that suppliers are leading the industry development. These stakeholders develop their respective timber engineering products, and the rest of the industry tries to follow. Architects are learning to design for timber structures but the participation of suppliers and supplier-builders is often needed, or drawings must often be redone or adjusted if suppliers have not been consulted. On top of that, security of timber buildings still must be proved, and it is mostly supported by suppliers. They drive safety exercises and tests and pay for them.

\subsubsection{The Structural Timber Building Industry Is Not Mass Standardized}

Even if structural timber building industry is subject to different codes and standards, construction with timber is not mass standardized yet. For example, glulam sizes are different from one product to another. Concrete and steel building materials benefit from international standardization and client usually have access to product specifications into which available elements and respective mechanical and physical properties are described. This is not the case for the structural timer building industry. Each supplier offers its specific and different products which ask for more efforts and knowledge from designers.

4.1.6. Labor Competition Explained by Lack of Specialists and of Timber Trained Employees

It is a characteristic of the industry; well-trained and experimented employees are scarce and rare. Since timber engineering is not taught in every civil engineering and architecture university and technical program, employees usually need to be trained once hired. It results in a competition between enterprises of the industry for skilled employees and can also limit enterprises growth.

\subsubsection{A Strong and Absolute Collaboration between Stakeholders Is Needed}

Collaboration is needed in all construction projects $[89,90]$. Therefore, since welltrained employees are scarce, knowledge about timber engineered products and timber construction requires really high degree of sharing. This promotes a very strong collaborative environment within the timber construction value chain even among potential 
competitors. This was also noted by Toppinen et al. [91]. Many interviewees mentioned their interest in working for the development of the industry and not only their own business. This was also pointed by Uusitalo and Lavikka [92]. Since work with these new products entails risks and does not yet benefit from established standardization, stakeholders rely on each other for both help and information sharing. Since building with wood products is still young and not yet standardized, information held by the most experimented is shared. This finding is consistent with Rogers' (2003) explanation that, when an innovation is in its early stages, interaction, communication and collaboration are high to mitigate risks.

\subsubsection{Participating to Conferences or Shows Is a Must}

Almost every stakeholder mentioned attendance at conferences as being a major conduit for knowledge sharing. Participation in conferences should be a part of all business models since it is arguably where the most advanced ideas are exposed and discussed. It is also an opportunity to meet with all members of the construction value chain. All types of businesses that make up the industry are at the same location at a given moment in time, thus offering the best scenario to establish new contacts and explore novel ideas. Great value can be extracted from such heterogeneous sets of contacts. Missing conferences would potentially prevent businesses from keeping up with this fast-growing industry.

4.1.9. Collaborative Procurement Modes Are Better Suited to Timber Structural Building Industry

When design and construction phases are planned simultaneously, construction times are usually better than when they are planned in subsequent phases. Collaborative types of contract procurement modes seem to be needed and justified. This way, less back and forth is required between architects and engineers responsible for design and other stakeholders in charge of the actual construction.

\subsubsection{Partnerships with Universities Are a Common Feature within the Industry}

The data collected show an intimate link between leading timber industry stakeholders and universities. Partnering with universities can lead to process innovations [93]. Many architects, engineers, suppliers and supplier-builders have commented on their collaboration with universities. They either do research in collaboration with university partners or have been (or are) teaching (as lecturers, adjuncts, instructors, etc.). Suppliers and especially supplier-builders collaborate with universities to develop their products or certify them.

\subsubsection{Prefabrication Is an Important Part of the Structural Timber Industry's Future}

Prefabrication's main advantages are decreased construction times and increased quality. In addition, conception, construction and installation are often led by the same team. Suppliers are involved in the conception process. The architects and engineers still must undertake the appropriate design and calculations for the building and the structure, but the other steps involve a smaller number of organizations since production and assembly are taken care of by the main stakeholder. Decreasing the complexity of a project as well as the number of workers and exchanges between them will naturally increase the efficiency of the building process. Pelli and Lähtinen [94] argued "Servitization and new business models could potentially contribute to a system transition in construction towards improved sustainability". Brady et al. [95] stated that "integrated solutions business models best opportunity is in the context of private finance initiatives in the public sector or large clients who require repeatable solutions in the private sector". Data also suggest that less marketing effort needs to be carried out by prefabrication specialists. 


\subsubsection{Strongly Regulated Work Environment}

The construction industry is strongly regulated [96]. This characteristic limits opportunities for innovations. Managing changes within that industry can be hazardous and costly. Country respective building codes do not always allow timber constructions and often limit its uses. Timber product suppliers are often the ones paying the price. They must prove their products are respecting Building code standards although they differ from the norm.

\subsubsection{Fragmented}

The structural timber building industry is fragmented as the construction industry is in general. Many actors are involved in a construction project using either steel, concrete or timber for its structural material. Communication can easily become an issue since so many workers are involved especially when using traditional contract procurement modes $[97,98]$.

\subsection{Rethinking the Business Model Canvas for the Structural Timber Construction Industry}

Difficulties to use the Osterwalder and Pigneur business model canvas in the Timber Building Industry could at least partially be explained by Aki, Pekuri and Haapasalo [34], who pointed out how business models in the industry are differently understood than in the academy. In the industry, business models are often expressed as business sectors or project portfolios, while in academia business models refer to a range of activities that allow firms to generate and deliver value, as explained in the Introduction. The construction industry is based on projects, bringing an ephemeral nature to value chains. Paradoxically, this industry is also very structured and regulated. Stakeholders cannot act independently since projects are executed in teams. Their respective business models are affected and modeled by the other construction value chain members' respective business model. This latter aspect results in few possibilities of business model differentiation, which leads to the argument that Osterwalder and Pigneur's [9] business model canvas would benefit from further adaptation to better suit the Timber Building Industry.

Indeed, while the Osterwalder and Pigneur business model canvas proved useful to structure data gathering for this study, it has some limitations and blind spots, as explained hereafter. For example, respondents' answers related to value proposition and key activities were very similar to one another. When asked about customer relationships, answers were also partial and unspecific. Precise information about costs and revenues were also difficult to obtain, but some participants nevertheless agreed to provide general information. Partnerships seen as formal agreements between two firms being were not well understood by interviewees. However, as already discussed, many usual interactions were rather presented as collaborative relationships.

Upon completion of this research, three major areas of improvement appear so relevant changes can be made to the business model canvas in order to increase its relevance to the wood building industry (Figure 4).

(1) The customer segment portion of the canvas should be split into three parts, namely the tenure (public or private), building types and geographic areas that firms prefer to address. This would allow better accounting for customer characteristics, experience, idiosyncrasies and preferences.

(2) Collaborative spaces should be added to all dimensions of the canvas. As shown in Figure 3, the word collaboration appears quite frequently in the canvas. Collaboration in the timber building industry appears as central to project success. This word is found in many elements that constitute the canvas, but it does not contain a specific area related to the concept. A way to improve the canvas so it better suits the industry would be to include an expression of the importance of collaboration to every dimension in the canvas. 


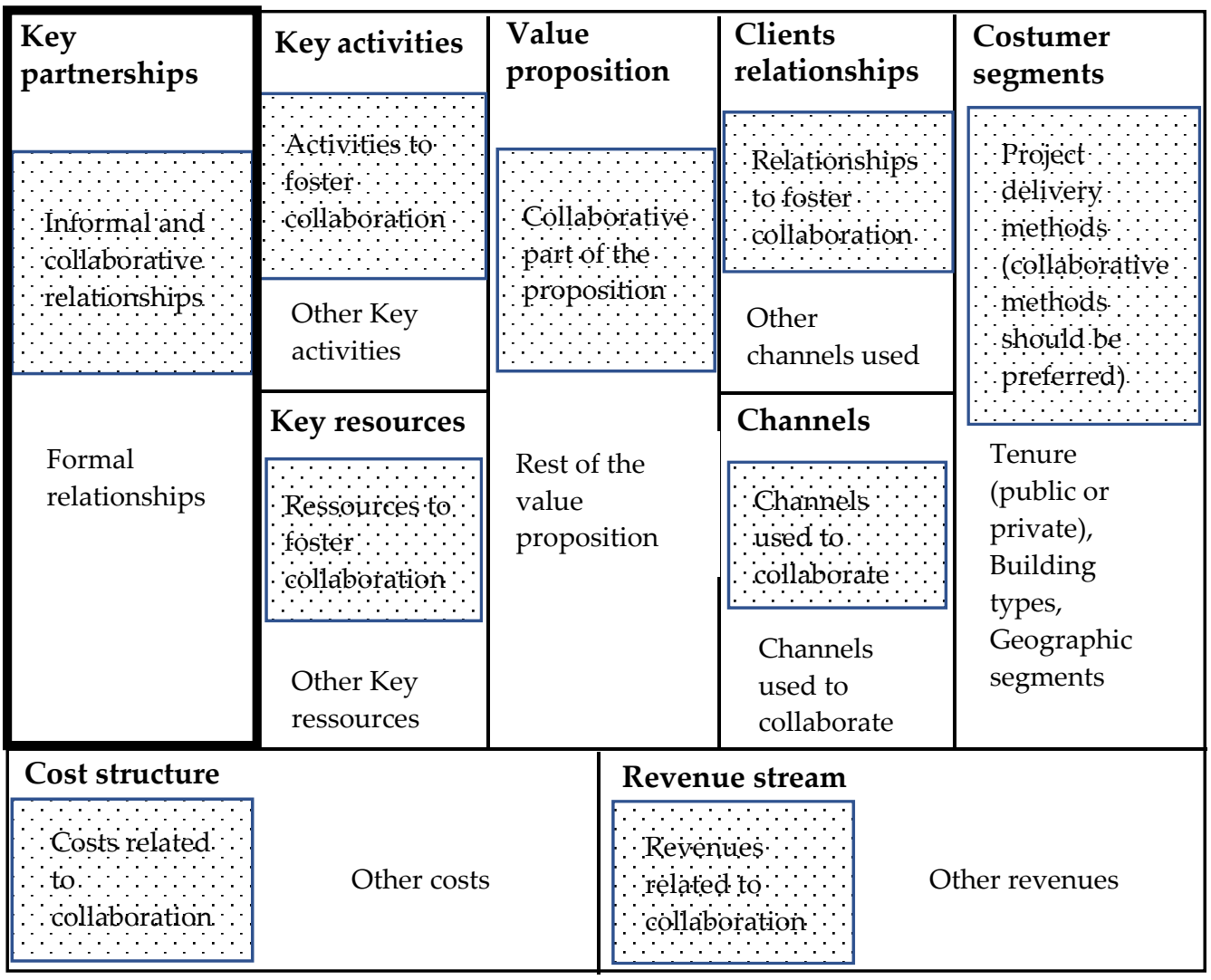

Figure 4. The revisited timber building industry business model canvas.

The value proposition's box should integrate a collaboration zone where a collaborative value proposition would be mentioned. For instance, one of the architect firms met offered training sessions for other architect firms wanting to learn wood building design. The customer segments portion of the canvas should include a zone for project delivery methods as well as methods favoring collaboration.

Customer relationships should integrate relationships developed to foster collaboration with the industry members. The same may be said for channels as some of them should be used to collaborate. In addition, certain revenues might this way be generated by this reliance on collaboration. Furthermore, part of the key activities would then be executed with the explicit goal of developing collaboration. As for key resources, some of them would also be used to collaborate.

When it comes to key partnerships, they should include informal relationships fostered to enhance collaboration as well as the more formal usual ones. Finally, the cost structure box would then of course integrate the cost of collaboration.

(3) The emphasis on partnerships should be central to business models. Beyond classical representations of the business model canvas, one important outcome of this research is showing the importance of partnerships as defining elements of the timber building sector. Partnerships are key to developing successful business models in this industry. They also remain a defining element of the value creation process for all stakeholders involved.

\section{Conclusions}

Timber used as a structural material in the non-residential building sector is steadily gaining in popularity.

This study's contribution is threefold. First, it innovates by mapping out the business models of the timber structure building industry. This work has not been done before. Second, it examines a range of business model key factors and features that are relevant for academics and practitioners alike. Those features should drive strategic, tactic and 
operational planning of business involved in timber structure construction projects. Third, it suggests a business model template to be used by timber building stakeholders interested in adapting their practices to overcome market shares. The business model presented in this study is the reflect of a fragmented and growing industry that is the timber structure construction. It could apply to any other emerging building construction material. More than anything else, training, R\&D and strong communication are heavily needed in such a context.

There are certain limitations to this work. Although it was possible to extract the main tendencies for the timber structure building industry business models, few timber buildings were studied. In addition, because of the availability of professionals at time of the fieldwork, it was impossible to meet and interview all main stakeholder's enterprises involved in the construction of the fifteen timber buildings. Finally, some regional characteristics may limit the application of the business model suggested.

Many research-oriented opportunities remain open for further enquiry. For instance, timber structure building industry business models could be compared with ones describing the steel and concrete building industry to find out what is specific to the timber building sector as they experience increasing rivalry with the latter's rise in popularity. For their part, managers in the industry can use these results to better adapt their business models to enter the emerging timber structure non-residential building market with a view to unlocking superior value creation.

Author Contributions: Conceptualization, A.G., Y.C., N.L. and P.B.; methodology, A.G., Y.C., N.L. and P.B.; software, A.G.; validation, Y.C., N.L. and P.B.; formal analysis, A.G.; investigation, A.G.; resources, P.B.; data curation, A.G.; writing-original draft preparation, A.G.; writing-review and editing, P.B. and A.G.; visualization, A.G.; supervision, Y.C., N.L. and P.B.; project administration, A.G.; and funding acquisition, P.B. All authors have read and agreed to the published version of the manuscript.

Funding: This research was funded by Natural Sciences and Engineering Research Council of Canada, ICP and CRD programs grant number IRCPJ 461745-12 and RDCPJ 445200-12 and by the industrial partners of the NSERC industrial chair on eco-responsible wood construction (CIRCERB).

Institutional Review Board Statement: Ethical review and approval were waived for this study, due to its administrative nature.

Informed Consent Statement: Informed consent was obtained from all subjects involved in the study.

Data Availability Statement: Restrictions apply to the availability of these data. Data was obtained from many companies and are available from the authors with the permission of concern companies.

Acknowledgments: The authors are grateful to Natural Sciences and Engineering Research Council of Canada for the financial support through its ICP and CRD programs (IRCPJ 461745-12 and RDCPJ 445200-12) as well as the industrial partners of the NSERC industrial chair on eco-responsible wood construction (CIRCERB).

Conflicts of Interest: The authors have no conflict of interest related to this work.

\section{Appendix A}

\section{List of questions for the interviews:}

1. Could you briefly tell me about your company's history?

2. What is the size of the company? (No. of employees, annual turnover) Value Proposition

3. In your opinion, what are its main strengths, what distinguishes your organization from its competitors?

\section{Key Activities}

4. Can you tell me about the company's main activities? In your opinion, what are the main reasons why customers decide to work with you? 
5. What expertise are they seeking?

6. What are your missions?
a. Types of projects
b. Types of contracts

\section{Client Relationships}

7. Who are your most important clients?

8. What kind of relationships do you have with your clients?

9. How do you start a relationship?

10. How do you maintain them over time?

\section{Customer Segments}

11. The CIRCERB Chair was created especially to promote the wooden building, something you are already doing brilliantly. How did you come to value wood constructions? How important is the use of wood as a structural material for non-residential buildings within your company today?

12. What other markets does your business occupy?

13. In your opinion, are they complementary or rather dominant compared to wood? $(\%$ wood vs. steel)

14. What are the motivations that lead your company to work on projects with wooden structures?

\section{Key Resources}

15. What is the level of expertise and training of your employees with wood? Professionals, technicians?

16. Are your employees comfortable to work on buildings with wooden structures upon hiring? How they develop the skills that allow them to work with wood?

17. Could I get a copy of the Operation "flowchart"?

18. Can you describe the company's human resources?

\section{Key Partnerships}

19. In your wooden structure projects such as what type of business relationships was established?

\section{Channels}

20. Who gets to know about your services and how do they learn about them? How do you reach your customers? What main visibility elements is the business using to be known/to improve its notoriety?

21. Do you have some examples of project that reflect your core business? Are projects your business card?

\section{Costs}

22. What are the main cost sources for your business? What are the drivers of these costs (client requests, supplier issues, unforeseen difficulties on a technical level, etc.)?

\section{Revenues}

23. What are the main revenue sources?

\section{Projects}

24. Was the building an exceptional or routine project for your business?

25. Why was wood chosen as structural material for this/these buildings?

26. What were the positive elements for you company about working on this/these building(s)?

27. What were difficulties or challenges faced when working on this/these building(s)?

28. If your company had to do this/these project(s) over again, what would you do differently? 
29. Would you like to share something else related to this/these project(s)?

30. Do you have anything to add?

\section{References}

1. Robichaud, F.; Kozak, R.; Richelieu, A. Wood use in nonresidential construction: A case for communication with architects. For. Prod. J. 2009, 59, 57-65.

2. Drouin, M. Étude de Marché Pour les bois de Structure dans la Construction non Résidentielle au Québec; 301010000; FPInnovations: Montréal, QC, Canada, 2015; p. 28.

3. Robichaud, F. L'utilisation du bois en Construction non Résidentielle au Québec: Enquête Auprès des Ingénieurs en Structure; 2001001474; FPInnovations: Montréal, QC, Canada, 2010; p. 25.

4. Chamberland, V.; Robichaud, F. Le Marché pour les bois de Structure dans la Construction non Résidentielle au Québec; 30107433; 30107433; FPInnovations: Montréal, QC, Canada, 2013; p. 25.

5. O'Connor, J.; Gaston, C. Potential for Increased Wood-Use in the N. A" Non-Residential Markets—Part II (Builder/Owner Survey); 3917; Forintek Cananda Corop: Vancouver, BC, Canada, 2004; p. 89.

6. Gaston, C.; Kozak, R.; O'Connor, J.; Fell, D. Potential for Increased Wood-Use in N.A. Non-Residential Markets; 2711; Forinteck Canada Corp: Vancouver, BC, Canada, 2001; p. 106.

7. Guy-Plourde, S.; Robichaud, F. Enquête sur la Construction non Résidentielle et Multifamiliale en Bois en 2020; Forest Economics Advisors: Port Coquitlam, BC, Canada, 2020; p. 14.

8. Michaelsen, J.; Tran, E. Analyse du Flux du Bois Pour la Scierie St-Roch de Kruger Avec L'utilisation de Parc de Transfert et de Camions hor Normes; Rapport de contrat confidentiel RC-0387-1; Feric: Toronto, ON, Canada, 2008.

9. Osterwalder, A.; Pigneur, Y. Business Model Generation: A Handbook for Visionaries, Game Changers, and Challengers; John Wiley \& Sons: Hoboken, NJ, USA, 2010.

10. Mathison, S. Why Triangulate? Educ. Res. 1988, 17, 13-17. [CrossRef]

11. Osterwalder, A.; Pigneur, Y.; Tucci, C.L. Clarifying Business Models: Origins, Present, and Future of the Concept. Commun. Assoc. Inf. Syst. 2005, 16, 1. [CrossRef]

12. Zott, C.; Amit, R.; Massa, L. The Business Model: Recent Developments and Future Research. J. Manag. 2011, 37, 1019-1042. [CrossRef]

13. Timmers, P. Business Models for Electronic Markets; 98-21; European Commission, Directorate-general III: Palo Alto, CA, USA, 1998.

14. Amit, R.; Zott, C. Value creation in E-business. Strat. Manag. J. 2001, 22, 493-520. [CrossRef]

15. Chesbrough, $\mathrm{H}$. The role of the business model in capturing value from innovation: Evidence from Xerox Corporation's technology spin-off companies. Ind. Corp. Chang. 2002, 11, 529-555. [CrossRef]

16. Magretta, J. Why Business Models Matter. Available online: https://hbr.org/2002/05/why-business-models-matter (accessed on 1 March 2019).

17. Morris, M.; Schindehutte, M.; Allen, J. The entrepreneur's business model: Toward a unified perspective. J. Bus. Res. 2005, 58, 726-735. [CrossRef]

18. Johnson, M.W.; Christensen, C.M.; Kagermann, H. Reinventing Your Business Model. Available online: https://hbr.org/2008/1 2/reinventing-your-business-model (accessed on 1 December 2019).

19. Teece, D.J. Business Models, Business Strategy and Innovation. Long Range Plan. 2010, 43, 172-194. [CrossRef]

20. George, G.; Bock, A.J. The Business Model in Practice and its Implications for Entrepreneurship Research. Entrep. Theory Pract. 2011, 35, 83-111. [CrossRef]

21. Casadesus-Masanell, R.; Ricart, J.E. How to Design a Winning Business Model. Available online: https:/ /hbr.org/2011/01/howto-design-a-winning-business-model (accessed on 1 January 2020).

22. Gulati, R. Silo Busting-How to Execute on the Promise of Customer Focus. Available online: https://hbr.org/2007/05/silobusting-how-to-execute-on-the-promise-of-customer-focus (accessed on 1 January 2020).

23. Joyce, A.; Paquin, R.L. The triple layered business model canvas: A tool to design more sustainable business models. J. Clean. Prod. 2016, 135, 1474-1486. [CrossRef]

24. Franceschelli, M.V.; Santoro, G.; Candelo, E. Business model innovation for sustainability: A food start-up case study. Br. Food J. 2018, 120, 2483-2494. [CrossRef]

25. Dijkman, R.; Sprenkels, B.; Peeters, T.; Janssen, A. Business models for the Internet of Things. Int. J. Inf. Manag. 2015, 35, 672-678. [CrossRef]

26. Porter, M.E. Competitive Advantage: Creating and Sustaining Superior Performance; The Free Press: New York, NY, USA, 1985; p. 557.

27. Demil, B.; Lecocq, X. Business Model Evolution: In Search of Dynamic Consistency. Long Range Plan. 2010, 43, 227-246. [CrossRef]

28. Linder, J.C.; Cantrell, S. Five business-model myths that hold companies back. Strat. Lead. 2001, 29, 13-18. [CrossRef]

29. Doz, Y.L.; Kosonen, M. Embedding Strategic Agility. Long Range Plan. 2010, 43, 370-382. [CrossRef]

30. Euchner, J.; Ganguly, A. Business Model Innovation in Practice. Res. Technol. Manag. 2014, 57, 33-39. [CrossRef]

31. Spieth, P.; Schneider, S. Business model innovativeness: Designing a formative measure for business model innovation. J. Bus. Econ. 2016, 86, 671-696. [CrossRef]

32. Foss, N.J.; Saebi, T. Fifteen Years of Research on Business Model Innovation. J. Manag. 2016, 43, 200-227. [CrossRef] 
33. Cosenz, F.; Bivona, E. Fostering growth patterns of SMEs through business model innovation. A tailored dynamic business modelling approach. J. Bus. Res. 2020, 1-12. [CrossRef]

34. Pekuri, A.; Pekuri, L.; Haapasalo, H. The role of business models in Finnish construction companies. Constr. Econ. Build. 2013, 13, 13-23. [CrossRef]

35. Pekuri, A.; Pekuri, L.; Haapasalo, H. Business models and project selection in construction companies. Constr. Innov. 2015, 15, 180-197. [CrossRef]

36. Mokhlesian, S.; Holmén, M. Business model changes and green construction processes. Constr. Manag. Econ. 2012, 30, 761-775. [CrossRef]

37. Pan, W.; Gibb, A.G.F.; Dainty, A.R.J. Perspectives of UK housebuilders on the use of offsite modern methods of construction. Constr. Manag. Econ. 2007, 25, 183-194. [CrossRef]

38. Pan, W.; Gibb, A.G.; Dainty, A.R. Leading UK housebuilders' utilization of offsite construction methods. Build. Res. Inf. 2008, 36, 56-67. [CrossRef]

39. Pan, W.; Goodier, C.I. House-Building Business Models and Off-Site Construction Take-Up. J. Arch. Eng. 2012, 18, 84-93. [CrossRef]

40. Andersson, N.; Lessing, J. Industrialization of construction: Implications on standards, business models and project orientation. Organ. Technol. Manag. Constr. Int. J. 2020, 12, 2109-2116. [CrossRef]

41. Goulding, J.; Pour Rahimian, F.; Arif, M.; Sharp, M. New offsite production and business models in construction: Priorities for the future research agenda. Arch. Eng. Des. Manag. 2015, 11, 163-184. [CrossRef]

42. Lessing, J.; Brege, S. Industrialized Building Companies' Business Models: Multiple Case Study of Swedish and North American Companies. J. Constr. Eng. Manag. 2018, 144, 05017019. [CrossRef]

43. Liu, G.; Li, K.; Zhao, D.; Mao, C. Business Model Innovation and Its Drivers in the Chinese Construction Industry during the Shift to Modular Prefabrication. J. Manag. Eng. 2017, 33, 04016051. [CrossRef]

44. Thuesen, C.; Hvam, L. Rethinking the Business Model in Construction by the Use of Off-Site System Deliverance: Case of the Shaft Project. J. Arch. Eng. 2013, 19, 279-287. [CrossRef]

45. Zhang, R.; Zhou, A.S.J.; Tahmasebi, S.; Whyte, J. Long-standing themes and new developments in offsite construction: The case of UK housing. Proc. Inst. Civ. Eng. Civ. Eng. 2019, 172, 29-35. [CrossRef]

46. Pardalis, G.; Mahapatra, K.; Mainali, B. Swedish construction MSEs: Simply renovators or renovation service innovators? Build. Res. Inf. 2019, 48, 67-83. [CrossRef]

47. Abuzeinab, A.; Arif, M.; Kulonda, D.J.; Awuzie, B.O. Green business models transformation: Evidence from the UK construction sector. Built Environ. Proj. Asset Manag. 2016, 6, 478-490. [CrossRef]

48. Abuzeinab, A.; Arif, M.; Qadri, M.A. Barriers to MNEs green business models in the UK construction sector: An ISM analysis. J. Clean. Prod. 2017, 160, 27-37. [CrossRef]

49. Duarte, S.; Cruzmachado, V. Modelling lean and green: A review from business models. Int. J. Lean Six Sigma 2013, 4, 228-250. [CrossRef]

50. Wang, L.; Toppinen, A.; Juslin, H. Use of wood in green building: A study of expert perspectives from the UK. J. Clean. Prod. 2014, 65, 350-361. [CrossRef]

51. Aho, I. Value-added business models: Linking professionalism and delivery of sustainability. Build. Res. Inf. 2013, 41, 110-114. [CrossRef]

52. Zhao, X.; Hwang, B.-G.; Lu, Q. Typology of business model innovations for delivering zero carbon buildings. J. Clean. Prod. 2018, 196, 1213-1226. [CrossRef]

53. Zhao, X.; Pan, W. Delivering Zero Carbon Buildings: The Role of Innovative Business Models. Procedia Eng. 2015, $118,404-411$. [CrossRef]

54. Zhao, X.; Pan, W. Co-productive interrelations between business model and zero carbon building. Built Environ. Proj. Asset Manag. 2017, 7, 353-365. [CrossRef]

55. Zhao, X.; Pan, W.; Lu, W. Business model innovation for delivering zero carbon buildings. Sustain. Cities Soc. 2016, 27, 253-262. [CrossRef]

56. Adams, K.T.; Osmani, M.; Thorpe, T.; Thornback, J. Circular economy in construction: Current awareness, challenges and enablers. Proc. Inst. Civ. Eng. Waste Resour. Manag. 2017, 170, 15-24. [CrossRef]

57. Munaro, M.R.; Tavares, S.F.; Bragança, L. Towards circular and more sustainable buildings: A systematic literature review on the circular economy in the built environment. J. Clean. Prod. 2020, 260, 121134. [CrossRef]

58. Górecki, J.; Núñez-Cacho, P.; Corpas-Iglesias, F.A.; Molina, V. How to convince players in construction market? Strategies for effective implementation of circular economy in construction sector. Cogent Eng. 2019, 6, 1-22. [CrossRef]

59. Brege, S.; Stehn, L.; Nord, T. Business models in industrialized building of multi-storey houses. Constr. Manag. Econ. 2013, 32, 208-226. [CrossRef]

60. Mayo, J. Solid Wood: Case Studies in Mass Timber Architecture, Technology and Design; Routeledge; Taylor \& Francis: New York, NY, USA, 2015; p. 346.

61. Höök, M.; Stehn, L.; Brege, S. The development of a portfolio of business models: A longitudinal case study of a building material company. Constr. Manag. Econ. 2015, 33, 334-348. [CrossRef]

62. Hurmekoski, E.; Jonsson, R.; Nord, T. Context, drivers, and future potential for wood-frame multi-story construction in Europe. Technol. Soc. Chang. 2015, 99, 181-196. [CrossRef] 
63. Carmines, E.G.; Zeller, R.A. Reliability and Validity Assessment; Sage Publications: Beverly Hills, CA, USA, 1979.

64. Cooper, H.; Hedges, L.V.; Valentine, J.C. The Handbook of Research Synthesis and Meta-Analysis; Russell Sage Foundation: New York, NY, USA, 2009; p. 632.

65. Cooper, D.R.; Schindler, P.S. Business Research Methods, 6th ed.; Irwin/McGraw-Hill: New York, NY, USA, 1998.

66. Ghauri, P.; Grønhaug, K.; Strange, R. Research Methods in Business Studies; FT Prentice Hall: Harlow, UK, 2005.

67. Heckathorn, D.D. Comment: Snowball versus respondent-driven sampling. Soc. Methodol. 2011, 41, 355-366. [CrossRef]

68. Poupart, J.; Deslauriers, J.-P.; Groulx, L.H.; Mayer, R.; Pires, A. La Recherche Qualitative: Enjeux Épistémologiques et Méthodologiques; Gaëtan Morin: Montréal, QC, Canada, 1997.

69. Mucchielli, A. Dictionnaire des Méthodes Qualitatives en Sciences Humaines et Sociales; Colin: Paris, France, 1996.

70. Bryman, A.; Bell, E. Business Research Methods, 4th ed.; Oxford University Press: Oxford, UK, 2015; p. 778.

71. Saunders, M.; Lewis, P.; Thornhill, A. Research Methods for business Students; Pearson Education Limited: Harlow, UK, $2012 ;$ p. 696.

72. Lessard-Hébert, M.; Goyette, G.; Boutin, G. La Recherche Qualitative, Fonde ments et Pratiques; Éditions Nouvelles: Montréal, QC, Canada, 1995; p. 124.

73. Tedlock, B. Ethnography and Ethographic Representation. In Handbook of Qualitative Research, 2nd ed.; Denzin, N.K., Lincoln, Y.S., Eds.; SAGE Publications Inc.: Thousand Oaks, CA, USA, 2000; pp. 455-486.

74. Fortin, A. L'observation Participante: Au Cœur de L'altérité. In Les Méthodes de la Recherche Qualitative; Deslauriers, J.-P., Ed.; Presses de L'université du Québec: Quebec City, QC, Canada, 1987; pp. 23-33.

75. Mintzberg, H. An Emerging Strategy of "Direct" Research. Adm. Sci. Q. 1979, 24, 582. [CrossRef]

76. L'Écuyer, R. Méthodologie de L'analyse Développementale de Contenu: Mé Thode GPS et Concept de Soi; Presses de l'Université du Québec: Quebec City, QC, Canada, 1990; p. 472.

77. Herbert, J. Using Unpublished Data: Error and Remedies; SAGE Publications: Newbury Park, CA, USA, $1984 ;$ p. 65.

78. Lincoln, Y.S.; Guba, E.G. Paradigmatic controversies, contradictions, and emerging confluencies. In Handbook of Qualitative Reasearch, 2nd ed.; Denzin, N.K., Lincoln, Y.S., Eds.; SAGE Publications Ltd.: Thousand Oaks, CA, USA, 2008 ; pp. $163-188$.

79. Silverman, D. Analysing Talk and Text. In Handbook of Qualitative Research, 2nd ed.; Denzin, N.K., Lincoln, Y.S., Eds.; SAGE Publications Inc.: Thousand Oaks, CA, USA, 2000; pp. 821-834.

80. Barratt, M. Understanding the meaning of collaboration in the supply chain. Supply Chain Manag. Int. J. 2004, 9, 30-42. [CrossRef]

81. Johnston, M.P. Secondary Data Analysis: A Method of which the Time Has Come. Qual. Quant. Methods Libr. 2014, 3, 619-626.

82. Miles, M.B.; Huberman, A.M. Qualitative Data Analysis, 2nd ed.; SAGE Publications: Thousand Oaks, CA, USA, $1994 ;$ p. 408.

83. Moher, D.; Liberati, A.; Tetzlaff, J.; Altman, D.G. The PRISMA Group. Preferred reporting items for systematic reviews and meta-analyses: The PRISMA statement. PLoS Med. 2009, 6, e1000097. [CrossRef]

84. Booth, A. Unpacking your literature search toolbox: On search styles and tactics. Health Inf. Libr. J. 2008, 25, 313-317. [CrossRef]

85. Nelson, J. Using conceptual depth criteria: Addressing the challenge of reaching saturation in qualitative research. Qual. Res. 2017, 17, 554-570. [CrossRef]

86. Gosselin, A.; Blanchet, P.; Lehoux, N.; Cimon, Y. Collaboration Enables Innovative Timber Structure Adoption in Construction Buildings 2018, 8, 183. [CrossRef]

87. Abuzeinaba, A.; Arifa, M. Stakeholder engagement: A green business model indicator. In Proceedings of the 4th International Conference on Building Resilience, Salford Quays, UK, 8-10 September 2014; pp. 505-512.

88. Churkina, G.; Organschi, A.; Reyer, C.P.O.; Ruff, A.; Vinke, K.; Liu, Z.; Reck, B.K.; Graedel, T.E.; Schellnhuber, H.J. Buildings as a global carbon sink. Nat. Sustain. 2020, 3, 269-276. [CrossRef]

89. Farnsworth, C.B.; Beveridge, S.; Miller, K.R.; Christofferson, J.P. Application, Advantages, and Methods Associated with Using BIM in Commercial Construction. Int. J. Constr. Educ. Res. 2014, 11, 1-19. [CrossRef]

90. Georgiadou, M.C. An overview of benefits and challenges of building information modelling (BIM) adoption in UK residential projects. Constr. Innov. 2019, 19, 298-320. [CrossRef]

91. Toppinen, A.; Miilumäki, N.; Vihemäki, H.; Toivonen, R.; Lähtinen, K. Collaboration and shared logic for creating value-added in three Finnish wooden multi-storey building projects. Wood Mater. Sci. Eng. 2019, 14, 269-279. [CrossRef]

92. Uusitalo, P.; Lavikka, R. Technology transfer in the construction industry. J. Technol. Transf. 2020, 1-30. [CrossRef]

93. Lavikka, R.; Seppänen, O.; Peltokorpi, A.; Lehtovaara, J. Fostering process innovations in construction through industryuniversity consortium. Constr. Innov. 2020, 20, 569-586. [CrossRef]

94. Pelli, P.; Lähtinen, K. Servitization and bioeconomy transitions: Insights on prefabricated wooden elements supply networks. J. Clean. Prod. 2020, 244, 118711. [CrossRef]

95. Brady, T.; Davies, A.; Gann, D. Can integrated solutions business models work in construction? Build. Res. Inf. 2005, 33, 571-579. [CrossRef]

96. Branco Pedro, J.; Meijer, F.; Visscher, H. Comparison of building permit procedures in European Union countries. In Proceedings of the COBRA 2011-RICS Construction and Property, Salford, Manchester, UK, 12-13 September 2011.

97. Egan, J. Rethinking Construction; Department of the Environment, Transport and the Regions: London, UK, 1998 ; p. 38.

98. Nawi, M.N.M.; Baluch, N.; Bahauddin, A.Y. Impact of Fragmentation Issue in Construction Industry: An Overview. In Proceedings of the MATEC Web of Conferences, Perak, Malaysia, 27 August 2014; EDP Sciences: Les Ulis, Île-de-France, France, 2014; Volume 15, p. 1009. 